\title{
Amino Acid Transport by Prosthecae of Asticcacaulis biprosthecum: Evidence for a Broad-range Transport System
}

\author{
By ERIC TAM AND JACK L. PATE* \\ Department of Bacteriology, University of Wisconsin, Madison, Wisconsin 53706, USA
}

(Received 17 December 1984 ; revised 17 May 1985)

\begin{abstract}
Prosthecae purified from cells of Asticcacaulis biprosthecum possess active transport systems that transport all 20 amino acids tested. Using ascorbate-reduced phenazine methosulphate in the presence of oxygen, all 20 amino acids are accumulated against a concentration gradient by isolated prosthecae. Results of experiments testing the inhibition of transport of one amino acid by another, and of experiments testing the exchange of exogenous amino acids with those preloaded in prosthecae, along with characteristics of mutants defective in amino acid transport, suggest the presence in prosthecae of three amino acid transport systems. One, the general or $\mathrm{G}$ system, transports at least 18 of the 20 amino acids tested. Another system, referred to as the proline or $\mathrm{P}$ system, transports seven amino acids (including proline) that are also transported by the $\mathrm{G}$ system. The third system transports only glutamate and aspartate, and is referred to as the acidic amino acid transport system, or A system.
\end{abstract}

\section{INTRODUCTION}

Cells of the bacterium Asticcacaulis biprosthecum go through a complex cycle during which swarmer cells, each with a polar flagellum and polar pili, develop into nonmotile prosthecate cells, each with polar holdfast material and two non-polar prosthecae (Pate et al., 1973). The prosthecate cell repeatedly produces swarmer cells by asymmetric division. These cells resemble members of the genus Caulobacter in all respects except the number of prosthecae produced and their position on the cell. Previous research showed that prosthecae removed from cells of $A$. biprosthecum possessed active transport systems for sugars and for four amino acids (Porter $\&$ Pate, 1975; Larson \& Pate, 1976), and it was suggested that prosthecae function to increase the surface area of cells, thereby giving their possessors a competitive advantage in nutrient-poor environments. Further characterization of the amino acid transport systems of prosthecae was undertaken as a step towards eventual elucidation of the selective advantage that prosthecae confer upon oligotrophs of the genera Asticcacaulis and Caulobacter.

\section{METHODS}

Source of reugents. L-i $\left.{ }^{1+} \mathrm{C}\right]$ A sparagine $\left(212 \mathrm{mCi} \mathrm{mmol}^{-1}\right), \mathrm{L}-\left[{ }^{1+} \mathrm{C}\right] \mathrm{cystine}\left(321 \mathrm{mCi} \mathrm{mmol}^{-1}\right), \mathrm{L}-\left[{ }^{1+} \mathrm{C}\right] \mathrm{glutamine}$ $\left(248 \mathrm{mCi} \mathrm{mmol}^{-1}\right), \mathrm{L}-\left[{ }^{1+} \mathrm{C}\right] \mathrm{glycine}\left(113 \mathrm{mCi} \mathrm{mmol}^{-1}\right), \mathrm{L}-\left[{ }^{1+} \mathrm{C}\right]$ histidine $\left(343 \mathrm{mCi} \mathrm{mmol}^{-1}\right), \mathrm{L}-\left[{ }^{1+} \mathrm{C}\right] \mathrm{methionine}$ $\left(293 \mathrm{mCi} \mathrm{mmol}^{-1}\right), \mathrm{L}-\left[^{i+} \mathrm{C}\right]$ proline $\left(283 \mathrm{mCi} \mathrm{mmol}^{-1}\right), \mathrm{L}-\left[{ }^{1+C}\right]$ tryptophan $\left(58 \mathrm{mCi} \mathrm{mmol}^{-1}\right)$, and ${ }^{1+} \mathrm{C}-1$ abelled, Lconfiguration alanine, arginine, aspartate, glutamate, isoleucine, leucine, lysine, phenylalanine, serine, threonine, tyrosine, and valine $\left(10 \mathrm{mCi} \mathrm{mmol}^{-1}\right.$ each) $[1 \mathrm{Ci}=37 \mathrm{GBu}]$ were purchased from New England Nuclear. D$\left[{ }^{1+} \mathrm{C}\right]$ Glucose $\left(251 \mathrm{mCi} \mathrm{mmol}^{-1}\right)$ was purchased from Amersham/Searle. 2,4-Dinitrophenol (DNP), carbonyl cyanide $m$-chlorophenylhydrazone (CCCP), phenazine methosulphate (PMS), L-canavanine, L-azetidine-2carboxylic acid. L-ascorbate, $\alpha$-methyl-DL-methionine, L-methionine-DL-sulphoxide, L-norleucine, $N$-acetyl-Dmethionine, $N$-acetyl-L-methionine, L-methionine amide, L-methionine methyl ester, glycyl-L-methionine, Lmethionylglycine, L-methionine-DL-sulphoximine, seleno-DL-methionine, DL-ethionine, D-methionine and

Abbretiations: PYE, peptone yeast extract medium: MS-B, mineral salts-biotin medium: KU, Klett units; CCCP, carbonyl cyanide $m$-chlorophenylhydrazone: PMS, phenazine methosulphate. 
unlabelled L-amino acids were from Sigma. All other chemicals used were of reagent grade and were obtained from commercial sources.

Organism and growth conditions. A. biprosthecum strain C-19 (ATCC 27554) was grown in either the peptone yeast extract (PYE) medium of Poindexter (1964) or in the mineral salts-biotin (MS-B) defined medium of Larson \& Pate (1975). Cultures were incubated on a rotary shaker at $25^{\circ} \mathrm{C}$. For growth experiments, cells were grown in flasks fitted with side-arms, and turbidity was measured in Klett units (KU) with a Klett-Summerson colorimeter

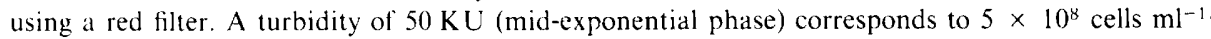

Preparation of isolated prosthecae. Prosthecae were removed from C-19 or mutant cells and purified by differential centrifugation as described by Jordan et al. (1974). Isolated prosthecae were suspended in 5 mm$\mathrm{MgSO}_{+}$to a concentration of about $5 \mathrm{mg}$ prosthecal protein $\mathrm{ml}^{-1}$, frozen $\mathrm{in} 1 \mathrm{ml}$ portions in an acetone dry ice bath, and stored at -72 " C.

Transport assays. The basic assay mixture $(500 \mu \mathrm{l})$ contained $50 \mathrm{~mm}$-Tris/ $\mathrm{HCl}(\mathrm{pH} 7 \cdot 4)$ or other buffers as indicated, $1 \mathrm{~mm}-\mathrm{MgCl}_{2}, 0 \cdot 1 \mathrm{mM}-\mathrm{PMS}, 20 \mathrm{~mm}$-ascorbate, about $100 \mu \mathrm{g}$ prosthecal protein suspended in $5 \mathrm{~mm}$ $\mathrm{MgSO}_{\downarrow}$ and an appropriate concentration of ${ }^{14} \mathrm{C}$-labelled substrate. When whole cells were used in the assay, a late-exponential (about $90 \mathrm{KU}$ ) culture in PYE medium was harvested and washed, and the pellet resuspended in $5 \mathrm{~mm}_{-} \mathrm{MgSO}_{+}$at a concentration of $1 \mathrm{~g}$ wet weight of cells per $15 \mathrm{ml} \mathrm{MgSO}{ }_{4}$. The whole-cell suspension $(20 \mu \mathrm{l})$ was then added to the reaction mixture. Inhibitors or other compounds were added to the mixture depending on the experiment. The reaction was started by the addition of ${ }^{1+} \mathrm{C}$-labelled substrate, and the mixture was vigorously aerated with water-saturated oxygen during incubation at $25^{\circ} \mathrm{C}$. The conditions were altered according to the purpose of the experiment. Samples $(100 \mu \mathrm{l})$ were taken from the reaction mixture at 15,30 and $45 \mathrm{~s}$, and each was put into $4 \mathrm{ml} 0.1 \mathrm{M}$ - $\mathrm{LiCl}$ to stop transport. The mixture was filtered through a Millipore HAWP $(0.45 \mu \mathrm{m})$ membrane filter, and the tube was washed with an additional $4 \mathrm{ml} 0 \cdot 1 \mathrm{M}-\mathrm{LiCl}$ and filtered as before. Dilutions and filtrations were all done within $30 \mathrm{~s}$. Filters were dried under a heat lamp and then placed in $10 \mathrm{ml}$ liquid scintillation fluid containing (per litre of toluene) $0.1 \mathrm{~g}$ POPOP and $4 \mathrm{~g}$ PPO in glass liquid scintillation vials; they were counted at about $93 \%$ efficiency in a Packard liquid scintillation spectrometer.

Fate of transported amino acids. A transport experiment on prosthecae from C-19 cells was done using each of 20 amino acids at a concentration of $20 \mu \mathrm{m}$. In each case, transport was allowed to proceed for $10 \mathrm{~min}$ at $25^{\circ} \mathrm{C}$ before diluting and filtering the reaction mixture. Immediately following filtration, each filter was placed into $2 \mathrm{ml}$ double-distilled water at $70^{\circ} \mathrm{C}$ and kept at that temperature for $60 \mathrm{~min}$. Each extract was lyophilized and then dissolved in $100 \mu \mathrm{l}$ double-distilled water. A $5 \mu \mathrm{l}$ sample of each concentrated extract was spotted at one edge of a silica gel thin-layer plate $(20 \times 20 \mathrm{~cm})$, and an equal volume of the labelled amino acid stock solution used in the transport experiment was spotted adjacent to the extract. Plates were developed in an ascending system with butanol/acetic acid/water $(80: 20: 20$, by vol.) until the solvent front was $10 \mathrm{~cm}$ from the starting point. An autoradiogram was prepared from each dried plate by placing a sheet of X-ray film in contact with the plate for 24 hat -70 " C.

Competition for transport between amino acids. The basic reaction mixture and the amount of prosthecae used were identical to those described for transport assays. The reaction was started by adding labelled and unlabelled substrates simultaneously to the reaction mixture to final concentrations of $10 \mu \mathrm{m}$ and $1 \mathrm{~mm}$, respectively. Samples were taken and filtered at 15,30 and $45 \mathrm{~s}$ intervals, and the filters were washed, dried and counted as described before. The amount of inhibition of transport of the labelled substrate by the unlabelled substrate was determined by comparing the rate of transport of the labelled substrate obtained above to that obtained from an identical run in which the unlabelled substrate was replaced by an equal volume of double-distilled water.

Exchange between amino acids. The basic reaction mixture (total $1 \mathrm{ml}$ ) was identical to those described for transport assays. Prosthecae were preloaded by adding a labelled amino acid to a concentration of $200 \mu \mathrm{M}$. After $10 \mathrm{~min}$, an unlabelled amino acid was added to the reaction mixture to a final concentration of $2 \mathrm{~mm}$. Samples $(100 \mu \mathrm{l})$ were taken and filtered at $0 \cdot 25,0 \cdot 60,1,2,3,4$ and $5 \mathrm{~min}$ after addition of the unlabelled substrate. Filters were washed, dried, and counted as before. A control was obtained by doing an identical run in which doubledistilled water was added instead of the unlabelled amino acid after the $10 \mathrm{~min}$ preloading period.

Reproducibility of transport experiments. All values on which the information shown in Tables $1,4,5$ and 6 was based were means of three measurements, none of which varied by more than $10 \%$ from the mean.

Isolation of transport-defectice mutants. Mutants defective in amino acid transport were isolated by picking colonies from plates containing amino acid analogues that inhibit the growth of wild-type cells. Late-exponential phase C -19 cells in PYE $(0.1 \mathrm{ml})$ were spread on MS-B plates containing analogues added to various concentrations. After incubation at $25^{\circ} \mathrm{C}$ for 4 to $5 \mathrm{~d}$, resistant colonies were picked off and purified by streaking onto fresh analogue-containing plates. Purified mutants were stored at $4{ }^{\circ} \mathrm{C}$ in agar deeps (PYE $+0.4 \%$ agar, $4 \mathrm{ml}$ per culture tube), transferred to new agar deeps once a month, and checked for analogue resistance before each experiment.

Phage sensitivity assays. The sensitivities of strain C-19 or of analogue-resistant mutants to various Asticcacaulis phages were determined by spotting each phage $\left(10^{7}\right.$ to $10^{8}$ p.f.u.) onto a lawn of cells according to a grid drawn on the bottom of the plate. The plates were incubated at $30^{\circ} \mathrm{C}$ and were examined for zones of clearing after 3 to $5 \mathrm{~d}$. The Asticcacaulis phages tested were $\mathrm{S}_{1}, \mathrm{~S}_{2}, \mathrm{~S}_{3}, \mathrm{~S}_{4}, \mathrm{~S}_{5}, \mathrm{M}_{1}, \mathrm{M}_{2}, \mathrm{M}_{4}, \mathrm{M}_{5}, \mathrm{ML}, \mathrm{ML}_{2}, \mathrm{ML}_{3}, \mathrm{Ml}_{5}, \mathrm{ML}_{6}, \mathrm{Ml}_{7}, \mathrm{ML}_{4}$, $\mathrm{ML}_{11}$, and $\mathrm{J}_{1}$; they were all propagated as described by Middleton \& Pate (1976). 


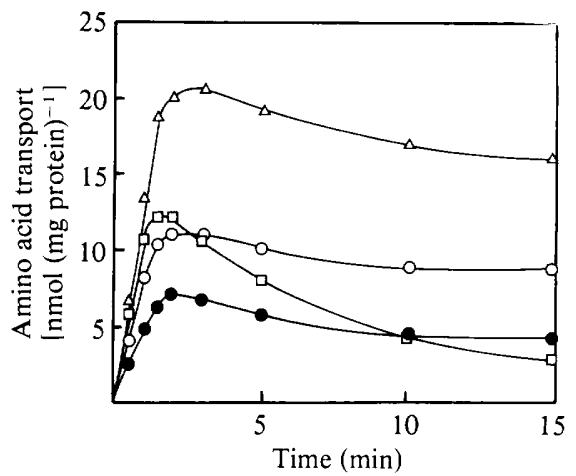

Fig. I. Time-course of transport of $L_{-}-\left[{ }^{1+} \mathrm{C}\right]$ histidine $(\triangle), L_{-}-\left[{ }^{1+} \mathrm{C}\right]$ glycine $(\square)$, L- $\left[{ }^{1+} \mathrm{C}\right]$ proline $(O)$, and L$\left[{ }^{1+} \mathrm{C}\right]$ methionine $(\mathrm{O})$ by $\mathrm{C}-19$ prosthecae. Each reaction mixture contained, in a $100 \mu 1$ total volume:

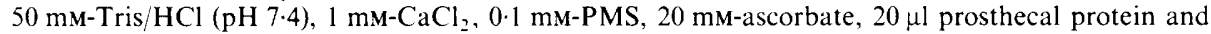
$20 \mu \mathrm{M}$-labelled amino acid. The reactions were allowed to run at $25^{\circ} \mathrm{C}$ for the times indicated and were then terminated. The points shown are means of triplicate samples, none of which varied by more than $6 \%$ from the mean.

Analogue sensitivity assays. To determine the sensitivities of strain C-19 or analogue-resistant mutants to various amino acid analogues, an exponential culture of each strain was spot-inoculated onto MS-B agar plates, each containing a different amino acid analogue. The plates were incubated at $30^{\circ} \mathrm{C}$ for $5 \mathrm{~d}$ and were then examined for growth of cells. The amino acid analogues tested and the concentration used for each were DLmethionine $\left(500 \mu \mathrm{g} \mathrm{ml}^{-1}\right)$, L-norleucine $\left(500 \mu \mathrm{g} \mathrm{ml}^{-1}\right), \alpha$-methyl-DL-methionine $\left(500 \mu \mathrm{g} \mathrm{ml}^{-1}\right)$, L-canavanine $\left(250 \mu \mathrm{g} \mathrm{ml}^{-1}\right)$ and L-azetidine-2-carboxylic acid $\left(25 \mu \mathrm{g} \mathrm{ml}^{-1}\right)$.

Protein determination. All protein assays were done using the Bio-Rad Protein Assay kit, based on an assay first described by Bradford (1976).

\section{RESULTS}

\section{Amino acid transport in C-19 prosthecae}

Time course of uptake. In the presence of an external energy source (ascorbate-reduced PMS), prosthecae prepared from wild-type cells grown in PYE broth were able to accumulate all 20 amino acids. The transport of histidine, glycine, proline and methionine plotted against time is shown in Fig. 1. In each case, the amount of amino acid accumulated reached a maximum after 1.5 to 2 min. No significant accumulation of substrate was observed when no energy source was added (data not shown). In similar experiments, transport of the other 16 amino acids tested displayed the same energy-dependent pattern as described above. Based on an internal prosthecal water space of $0.52 \mu \mathrm{l}$ (mg protein) $)^{-1}$ (Larson \& Pate, 1976), all amino acids tested were accumulated inside prosthecae at concentrations 500 to 2000 times higher than their external concentrations.

Fate of transported substrates. Autoradiograms of thin-layer plates with chromatographed extracts and controls for transported amino acids are shown in Fig. 2. The results indicated that none of the amino acids tested was metabolized after transport. Two or more spots were present in some of the controls (Met, Trp, Arg, Ile, Lys, Tyr), indicating the presence of contaminating amino acids or of oxidation products of the labelled amino acids. In these cases, the radioactivity of the corresponding prosthecal extracts always migrated with one or more spots in the control; additional labelled compounds, not present in the control, were never seen in prosthecal extracts.

Effects of energy inhibitors on methionine transport. The effects of various energy poisons on the initial rate of methionine transport in C-19 prosthecae were determined (Table 1). Inhibitors of respiration (cyanide, azide) and proton conductors (DNP, CCCP) eliminated transport, whereas arsenate, which inhibits ATP synthesis, failed to inhibit transport. In fact, arsenate increased the initial rate of methionine transport in C-19 prosthecae at all concentrations tested. In addition (not shown in Table 1), transport of methionine was eliminated in the absence: of oxygen. 

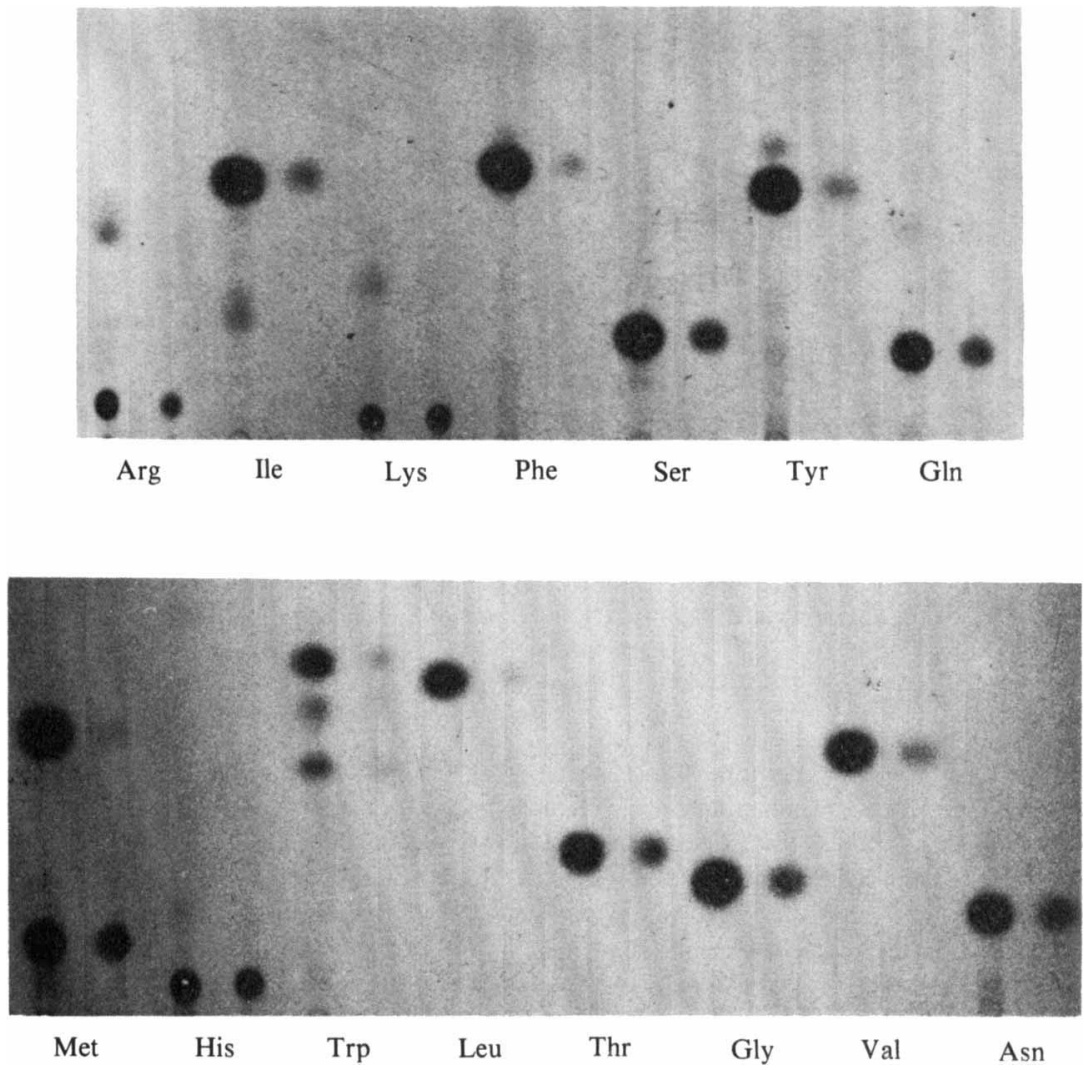

Fig. 2. Autoradiograms prepared from thin-layer chromatograms of prosthecal extracts and amino acid controls. For each amino acid indicated in the figure, the left lane represents the ${ }^{1+} \mathrm{C}-$ labelled amino acid control, and the right lane represents an extract prepared from prosthecae that had been allowed to accumulate the labelled amino acid for $10 \mathrm{~min}$ before terminating transport.

Table 1. Initial rates of transport of $\mathrm{L}-\left[{ }^{14} \mathrm{C}\right]$ methionine in $\mathrm{C}-19$ prosthecae in the presence of inhibitors

The basic reaction mixure contained, in a $100 \mu \mathrm{l}$ total volume: $50 \mathrm{~mm}-\mathrm{Tris} / \mathrm{HCl}(\mathrm{pH} 7 \cdot 4), 1 \mathrm{~mm}-\mathrm{CaCl}_{2}$, $0.1 \mathrm{~mm}-\mathrm{PMS}, 20 \mathrm{~mm}$-ascorbate and $20 \mu \mathrm{l}$ prosthecal suspension. The final concentration of $\mathrm{L}^{-}$ $\left[{ }^{1+} \mathrm{C}\right]$ methionine was $20 \mu \mathrm{M}$. The values are expressed as a percentage of the accumulation of the control, which is expressed as $100 \%$. The rate of accumulation of the control was $0.52 \pm 0.07 \mathrm{nmol}(\mathrm{mg}$ protein $)^{-1} \min ^{-1}$.

\begin{tabular}{cccccc}
$\begin{array}{c}\text { Inhibitor } \\
\text { concn } \\
(\mu \mathrm{M})\end{array}$ & \multicolumn{5}{c}{ Net transport (percentage of control) } \\
\cline { 3 - 5 } & DNP & CCCP & KCN & $\begin{array}{c}\text { Sodium } \\
\text { arsenate }\end{array}$ & $\mathrm{NaN}_{3}$ \\
$0 \cdot 1$ & 100 & 100 & 100 & 100 & 100 \\
1 & & 100 & & & \\
10 & & 71 & & & \\
100 & 74 & 5 & & & \\
1000 & 28 & & 2 & 194 & 78 \\
10000 & 2 & & 0 & 164 & 21 \\
& & & 0 & 150 & 3
\end{tabular}




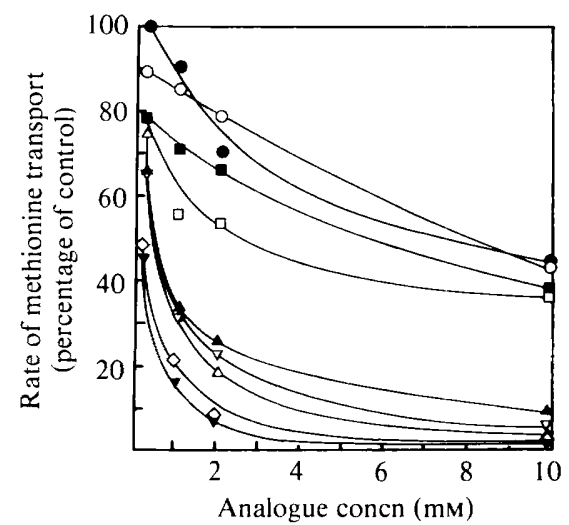

Fig. 3. Effects of methionine analogues on the rate of transport of $\mathrm{L}-\left[{ }^{1+} \mathrm{C}\right]$ methionine by $\mathrm{C}-19$ prosthecae. Inhibitors used were L-methionine $(\boldsymbol{\nabla})$ and the analogues D-methionine $(\nabla), N$-acetyl-Lmethionine $(\bigcirc)$, L-methionine-DL-sulphoximine ( $)$, L-methionine methyl ester $(\boldsymbol{\square})$, L-methionine-DLsulphoxide $(\square)$, DL-ethionine $(\boldsymbol{\Delta})$, seleno-DL-methionine $(\triangle)$, and L-norleucine $(\diamond)$. Each reaction mixture contained, in a $100 \mu \mathrm{l}$ total volume: $50 \mathrm{~mm}-\mathrm{Tris} / \mathrm{HCl}(\mathrm{pH} 7 \cdot 4), 1 \mathrm{~mm}-\mathrm{CaCl}_{2}, 0.1 \mathrm{~mm}-\mathrm{PMS}$, $20 \mathrm{~mm}$-ascorbate, and $20 \mu \mathrm{M}-\mathrm{L}-\left[{ }^{1+} \mathrm{C}\right]$ methionine. The points shown are means of triplicate samples, none of which varied by more than $5^{\circ}$, from the mean.

Effects of methionine analogues on methionine transport. When present at a concentration 500fold greater than the methionine concentration used, all analogues tested inhibited L-methionine transport (Fig. 3), indicating that all these analogues share the same transport systems with Lmethionine. The most potent inhibitors, L-norleucine, seleno-DL-methionine and DL-ethionine, inhibited L-methionine transport by more than $94 \%$, while the other analogues tested inhibited L-methionine transport by $35 \%$ to $65 \%$. Some stereospecificity of the transport system was shown by the greater inhibition due to unlabelled L-methionine than to unlabelled D-methionine.

Competition experiments. Every amino acid tested except aspartate, glutamate and proline strongly inhibited ( $>70 \%$ inhibition) the transport of most other amino acids (Fig. 4). Aspartate and glutamate inhibited the transport of each other, but they only weakly (or not at all) inhibited the transport of other amino acids, and their transport was only weakly (or not at all) inhibited by other amino acids. The transport of proline into prosthecae was strongly inhibited by most other amino acids (but not by aspartate and glutamate), but proline only weakly (no more than $50 \%$ ) inhibited the transport of other amino acids. The transport of amino acids was not inhibited by D-glucose, $\mathrm{NH}_{+}^{+}$(data not shown) or $\mathrm{NH}_{3} \mathrm{CH}_{3}$, indicating that the transport systems under study are specific for amino acids only.

Exchange between amino acids. When two solutes share the same transport system, the addition of one solute to the reaction mixture can accelerate the efflux of the other solute which was previously accumulated. This phenomenon is called exchange or counterflow (Rosenberg \& Wilbrandt, 1957). The effects of various amino acids on the efflux of $\mathrm{L}-\left[{ }^{1+} \mathrm{C}\right]$ histidine previously accumulated in C-19 prosthecae were determined as described in Methods (Fig. 5). Except for proline, aspartate and glutamate, which did not cause loss of accumulated label, all other amino acids caused a rapid efflux of accumulated histidine from prosthecae, at a rate similar to the initial rate of transport of the $\mathrm{L}-\left[{ }^{1+} \mathrm{C}\right]$ histidine.

Constitutice amino acid transport. In one experiment, prosthecae were prepared from C-19 cells grown in MS-B with $5 \mathrm{mM}-\left(\mathrm{NH}_{4}\right)_{2} \mathrm{SO}_{4}$ as the sole nitrogen source (cells are not nitrogen limited at this concentration). Prosthecae from such cells transported histidine, and, as with prosthecae from PYE-grown cells, all amino acids except glutamate, aspartate, and proline inhibited the transport of histidine (data not shown). Prosthecae used in all other experiments reported here were from PYE-grown cells. 


\begin{tabular}{|c|c|c|c|c|c|c|c|c|c|c|c|c|c|c|c|c|c|c|c|}
\hline \multirow{2}{*}{$\begin{array}{l}\text { Labelled } \\
\text { amino acid }\end{array}$} & \multicolumn{19}{|c|}{ Inhibition of transport by unlabelled amino acid } \\
\hline & Ala & Arg & Asn & Asp & Glu & $\mathrm{Gln}$ & Gly & His & Ile & Leu & Lys & Met & Phe & Pro & Ser & Thr & $\operatorname{Trp}$ & Val & $\mathrm{NH}_{3} \mathrm{CH}_{3}$ \\
\hline \multicolumn{20}{|l|}{$\mathrm{Ala}$} \\
\hline \multicolumn{20}{|l|}{ Arg } \\
\hline \multicolumn{20}{|l|}{ Asn } \\
\hline \multicolumn{20}{|l|}{ Asp } \\
\hline \multicolumn{20}{|l|}{ Glu } \\
\hline \multicolumn{20}{|l|}{ Gln } \\
\hline \multicolumn{20}{|l|}{ Gly } \\
\hline \multicolumn{20}{|l|}{ His } \\
\hline \multicolumn{20}{|l|}{ Ile } \\
\hline \multicolumn{20}{|l|}{ Leu } \\
\hline \multicolumn{20}{|l|}{ Lys } \\
\hline \multicolumn{20}{|l|}{ Met } \\
\hline \multicolumn{20}{|l|}{ Phe } \\
\hline \multicolumn{20}{|l|}{ Pro } \\
\hline \multicolumn{20}{|l|}{ Ser } \\
\hline \multicolumn{20}{|l|}{ Thr } \\
\hline \multicolumn{20}{|l|}{ Tyr } \\
\hline Val & & & & & & & & & & & & & & & & & & & \\
\hline
\end{tabular}

Fig. 4. Competition for amino acid transport in C-19 prosthecae. Each reaction mixture contained, in a $100 \mu \mathrm{l}$ total volume: $50 \mathrm{mM}$-Tris $/ \mathrm{HCl}\left(\mathrm{pH} \mathrm{7.4)}, 1 \mathrm{~mm}-\mathrm{CaCl}_{2}, 0 \cdot 1 \mathrm{~mm}-\mathrm{PMS}, 20 \mathrm{~mm}\right.$-ascorbate and $20 \mu \mathrm{l}$ prosthecal suspension. The final concentrations of the $\mathrm{L}^{-14} \mathrm{C}$-labelled amino acid and the unlabelled amino acid were $10 \mu \mathrm{M}$ and $1 \mathrm{mM}$, respectively. Labelled cystine, phenylalanine, tyrosine, and unlabelled cystine and tyrosine were not tested. $\square, 81-100 \%$ inhibition; 四, $51-80 \%$ inhibition; 冒, $41-50 \%$ inhibition; 瑓, 0-40\% inhibition.

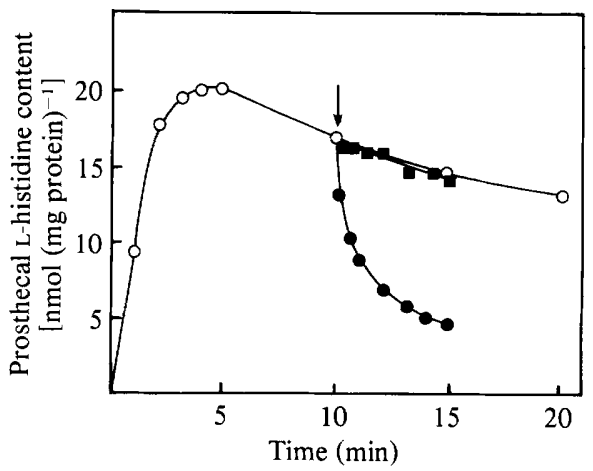

Fig. 5. Effects of the amino acids proline ( $\square$ ) and arginine (O) on efflux of $\mathrm{L}_{-}-\left[{ }^{14} \mathrm{C}\right]$ histidine from preloaded $\mathrm{C}-19$ prosthecae. The reaction mixture contained $50 \mathrm{~mm}-\mathrm{Tris} / \mathrm{HCl}(\mathrm{pH} 7 \cdot 4), 1 \mathrm{mM}-\mathrm{CaCl}_{2}$, $0.1 \mathrm{mM}$-PMS, $20 \mathrm{mM}$-ascorbate, and $20 \mu \mathrm{l}$ prosthecal suspension. The reaction was started by adding $200 \mu \mathrm{M}-\mathrm{L}-\left[{ }^{+} \mathrm{C}\right]$ histidine $(\mathrm{O})$. After $10 \mathrm{~min}$, unlabelled amino acid was added to a final concentration of $2 \mathrm{~mm}$ (arrow), and loss of preloaded label was followed for $5 \mathrm{~min}$. Adding unlabelled aspartate or giutamate to prosthecae preloaded with $\mathrm{L}-\left[{ }^{1+} \mathrm{C}\right]$ histidine gave the same results as were obtained by adding proline, and the addition of any of the other 15 amino acids tested gave results similar to those shown for the addition of arginine. 
Table 2. Information on the origin of various amino acid analogue-resistant mutants Analogue-resistant mutants were isolated as described in Methods. The values shown are based on actual numbers of mutants isolated and on viable counts of their parental strain before exposure to the analogues. Viable counts were done in triplicate and the means calculated; variation from the mean was less than $5 \%$.

\begin{tabular}{cllcccc}
$\begin{array}{c}\text { Mutant } \\
\text { designation }\end{array}$ & \multicolumn{1}{c}{$\begin{array}{c}\text { Analogue* } \\
\text { Ethr }\end{array}$} & Analogue of & $\begin{array}{c}\text { Analogue } \\
\text { concn } \\
\left(\mu \mathrm{g} \mathrm{ml}^{-1}\right)\end{array}$ & $\begin{array}{c}\text { No. of } \\
\text { mutants }\end{array}$ & $\begin{array}{c}\text { Parental } \\
\text { strain }\end{array}$ & $\begin{array}{c}\text { Mutant } \\
\text { frequency }\end{array}$ \\
Nor $^{r}$ & L-Ethionine & Methionine & 500 & 10 & $\mathrm{C}-19$ & $10^{-7}$ \\
$\mathrm{Mem}^{r}$ & $\alpha$-Methyl-DL-methionine & Methionine & 500 & 5 & $\mathrm{C}-19$ & $10^{-7}$ \\
$\mathrm{Can}^{r}$ & L-Canavanine & Methionine & 500 & 5 & $\mathrm{C}-19$ & $10^{-8}$ \\
Azer $^{r}$ & L-Azetidine-2-carboxylic acid & Arginine & 250 & 2 & $\mathrm{C}-19$ & $10^{-8}$ \\
& & Proline & 25 & 6 & Eth-2 & $10^{-8}$ \\
& & & 25 & 0 & $\mathrm{C}-19$ & $<10^{-9}$
\end{tabular}

* Analogue used in selection of mutants.

Table 3. Growth of wild-type cells and analogue-resistant mutants in various media

The media PYE and MS-B were described in Methods. DL-Ethionine (Eth), L-canavanine (Can), and Lazetidine-2-carboxylic acid (Aze) were added to MS-B at concentrations of $500 \mu \mathrm{g} \mathrm{ml}^{-1}, 250 \mu \mathrm{g} \mathrm{ml}^{-1}$ and $25 \mu \mathrm{g} \mathrm{mi}^{-1}$ respectively. $t_{\mathrm{d}}$, Doubling time (h); KU, final turbidity attained (Klett units); NG, no growth. The values shown are means of results from three growth experiments for each strain and each condition. No single value varied from the mean by more than $1 \%$.

\begin{tabular}{|c|c|c|c|c|c|c|c|c|}
\hline \multirow[b]{2}{*}{ Medium } & \multicolumn{2}{|c|}{$C-19$} & \multicolumn{2}{|c|}{$E^{t h}-2$} & \multicolumn{2}{|c|}{$\operatorname{Can}^{r}-2$} & \multicolumn{2}{|c|}{$A z e^{r}-1$} \\
\hline & $t_{\mathrm{d}}$ & $\mathrm{KU}$ & $t_{\mathrm{d}}$ & $\mathrm{KU}$ & $t_{\mathrm{d}}$ & $\mathrm{KU}$ & $t_{\mathrm{d}}$ & $\mathbf{K U}$ \\
\hline PYE & $5 \cdot 8$ & 125 & $8 \cdot 0$ & 90 & 8.0 & 90 & $17 \cdot 5$ & 40 \\
\hline MS-B & $3 \cdot 0$ & 100 & $3 \cdot 0$ & 95 & $3 \cdot 0$ & 96 & $4 \cdot 5$ & 90 \\
\hline $\mathrm{MS}-\mathrm{B}+\mathrm{Eth}$ & NG & $\mathrm{NG}$ & $6 \cdot 0$ & 102 & $5 \cdot 5$ & 105 & $5 \cdot 0$ & 92 \\
\hline $\mathrm{MS}-\mathrm{B}+\mathrm{Can}$ & NG & $\mathrm{NG}$ & $5 \cdot 8$ & 96 & $5 \cdot 8$ & 98 & $5 \cdot 0$ & 95 \\
\hline $\mathrm{MS}-\mathrm{B}+\mathrm{Aze}$ & NG & $\mathrm{NG}$ & NG & NG & NG & NG & 4.9 & 102 \\
\hline
\end{tabular}

\section{Transport-defective mutants}

Isolation of mutants. Mutants resistant to the amino acid analogues DL-ethionine, $\alpha$-methyl-DLmethionine, L-norleucine, L-canavanine, and L-azetidine-2-carboxylic acid were isolated as described in Methods. Mutants resistant to the first four analogues were derived from wild-type cells, while those resistant to L-azetidine-2-carboxylic acid were obtained from one of the ethionine-resistant mutants $\left(\mathrm{Eth}^{\mathrm{r}}-2\right)$, but could not be obtained from wild-type cells. Information on the concentrations of analogues used for mutant selections, the number of mutants obtained, the mutant frequency for each type, and the three-letter designation of each type is listed in Table 2.

All analogue-resistant mutants were tested for their sensitivities to bacteriophages that infect wild-type (C-19) cells: all were sensitive to all phages tested. When examined by phase-contrast microscopy, all mutants were identical in appearance to wild-type cells, producing prosthecate and swarmer cells and producing rosettes of polarly attached cells. When tested for their sensitivities to the five analogues used in mutant selections, Ethr and $\mathrm{Can}^{r}$ mutants were resistant to all but L-azetidine-2-carboxylic acid, Nor ${ }^{r}$ mutants were resistant only to Lnorleucine, $\mathrm{Mem}^{r}$ mutants were resistant only to $\alpha$-methyl-DL-methionine and Azer mutants were resistant to all five analogues. Wild-type (C-19) cells showed no growth in the presence of any of the analogues tested.

Growth of analogue-resistant mutants in various media. Growth of the mutants $\mathrm{Eth}^{\mathrm{r}}-2, \mathrm{Can}^{\mathrm{r}}-2$ and $\mathrm{Aze}^{\mathrm{r}}-1$ in the complex medium (PYE) and in the defined medium (MS-B) with and without various amino acid analogues was tested. The doubling times $\left(t_{\mathrm{d}}\right)$ and the maximum turbidities $(\mathrm{KU})$ attained by wild-type cells and mutants are shown in Table 3 . Wild-type cells grew almost twice as fast in MS-B as in PYE, but achieved a slightly lower maximum turbidity in MS-B. No growth of wild-type cells occurred in MS-B with any of the amino acid analogues. Both $\mathrm{Eth}^{\mathrm{r}-2}$ 
Table 4. Transport of amino acids by prosthecae from three types of analogue-resistant mutants

The reaction mixture continined, in a $100 \mu l$ total volume: $50 \mathrm{~mm}-\mathrm{Tris} / \mathrm{HCl}(\mathrm{pH} 7 \cdot 4), 1 \mathrm{~mm}-\mathrm{CaCl}_{2}, 0 \cdot 1$ mM-PMS, $20 \mathrm{~mm}$-ascorbate and $20 \mu \mathrm{l}$ prosthecal suspension. Concentrations of ${ }^{1+} \mathrm{C}$-labelled amino acids were $20 \mu \mathrm{M}$. The pattern of transport shown for each type of mutant was obtained with all mutants of that type. +. Amino acid transported as well as wild-type prosthecae; - , no transport of the amino acid: $D$, transport decreased by about $30 \%$ of wild-type value.

$\begin{array}{cccccccc}\begin{array}{c}\text { Amino } \\ \text { acid }\end{array} & \text { Eth }^{r} & \text { Can }^{r} & \text { Aze }^{r} & \begin{array}{c}\text { Amino } \\ \text { acid }\end{array} & \text { Eth }^{r} & \text { Can }^{r} & \text { Aze }^{r} \\ \text { Ala } & + & + & - & \text { His } & - & - & - \\ \text { Cys } & + & + & - & \text { Ile } & - & - & - \\ \text { Gly } & + & + & - & \text { Leu } & - & - & - \\ \text { Pro } & + & + & - & \text { Lys } & - & - & - \\ \text { Ser } & + & + & - & \text { Met } & - & - & - \\ \text { Thr } & + & + & - & \text { Phe } & - & - & - \\ \text { Val } & + & + & - & \text { Trp } & - & - & - \\ \text { Arg } & - & - & - & \text { Tyr } & - & - & - \\ \text { Asn } & - & - & - & \text { Asp } & \text { D } & \text { D } & \text { D } \\ \text { Gln } & - & - & - & \text { Glu } & \text { D } & \text { D } & \text { D }\end{array}$

and $\mathrm{Can}^{\mathrm{r}}-2$ mutants, which were isolated as resistant to the analogues L-ethionine and Lcanavanine, respectively, grew slower in PYE than did wild-type cells, but had the same growth rate in MS B as did wild-type cells. Both of these mutants grew in MS-B with either L-ethionine or L-canavanine added, but not in MS-B with L-azetidine-2-carboxylic acid. The Azer-1 mutant grew in MS-B with any of the three analogues added. Cells of the Azer-1 mutant grew much slower in PYE than did the $\mathrm{Eth}^{\mathrm{r}-2}$ and $\mathrm{Can}^{\mathrm{r}-2}$ mutants, but the growth of $\mathrm{Aze}^{\mathrm{r}-1}$ in MS-B, and in MS-B with L-ethionine or L-canavanine was about the same as the growth of the Ethr-2 and Can $\mathrm{r}-2$ mutants in these media.

Amino acid transport in prosthecae prepared from analogue-resistant mutants. Prosthecae prepared from all mutants were tested for their ability to transport amino acids. None of the Mem $^{r}$ or Nor ${ }^{r}$ mutants was defective in amino acid transport. Transport of all except nine amino acids was completely eliminated in prosthecae of all $\mathrm{Eth}^{\mathrm{r}}$ and $\mathrm{Can}^{\mathrm{r}}$ mutants (Table 4). Of these nine amino acids, aspartate and glutamate transport by the mutants was decreased by about $30 \%$ while the transport of the others (Ala, Cys, Gly, Pro, Ser, Thr, Val) was equal to that in wild-type prosthecae. Prosthecae prepared from Aze ${ }^{r}$ mutants were incapable of transporting any amino acid except aspartate and glutamate (Table 4). The rates of transport of these two amino acids were the same as in their parent strain, Eth'-2. Transport experiments were also done with whole cells of the various mutants, and identical results were observed (data not shown).

\section{Competition and exchange in C-19 and Ethr-2 prosthecae}

Results of competition experiments on prosthecae prepared from C-19 or Eth ${ }^{\mathrm{r}}-2$ cells are shown in Table 5. Two amino acids (glycine and proline) of the nine that are transported by Eth $\mathrm{r}^{\mathrm{r}}$ 2 prosthecae were used as the labelled amino acids in these experiments, and the effects on their transport of various unlabelled amino acids were determined. The amino acids are grouped in Table 5 according to patterns of transport in mutants, and the groups are numbered for convenience of discussion. The seven amino acids in group I and the two in group III are transported by all $\mathrm{Eth}^{r}$ and $\mathrm{Can}^{r}$ mutants, while those in group II are not. Only group III amino acids are transported by Aze ${ }^{r}$ mutants. As shown in the table, group II amino acids inhibit transport of group I amino acids in wild-type but not in mutant prosthecae. Furthermore, proline is a more effective inhibitor of glycine transport in mutant prosthecae than in wild-type prosthecae, and group III amino acids are only weakly inhibitory in both types of prosthecae.

An experiment was done to see if proline is generally a better inhibitor of transport in mutant prosthecae than in wild-type prosthecae; the results are shown in the last two columns of Table 5. Except for proline itself, there was a shift from partial inhibition in wild-type prosthecae to complete inhibition by proline of the transport of all group I amino acids in mutant prosthecae. 
Table 5. Inhibition of transport in C-19 and Ethr-2 prosthecae

The basic reaction mixture contained $50 \mathrm{~mm}-\mathrm{Tris} / \mathrm{HCl}(\mathrm{pH} \mathrm{7.4}), 1 \mathrm{~mm}-\mathrm{CaCl}_{2}, 0 \cdot 1 \mathrm{~mm}-\mathrm{PMS}, 20 \mathrm{~mm}$ ascorbate, and $20 \mu \mathrm{l}$ prosthecal suspension. Prosthecae were prepared from cells of strain $\mathrm{C}-19$ or Eth 2 , as indicated. Concentrations of labelled and unlabelled amino acids in competition experiments were $20 \mu \mathrm{M}$ and $2 \mathrm{mM}$, respectively. Values are expressed as percentage inhibition of transport of the labelled amino acid in the presence of the unlabelled amino acid. ND, Not done; NA, not applicable.

\begin{tabular}{|c|c|c|c|c|c|c|}
\hline \multirow{2}{*}{$\begin{array}{l}\text { Amino } \\
\text { acid }\end{array}$} & \multicolumn{2}{|c|}{$\begin{array}{c}\text { Inhibition of } \\
\text { Gly transport* }\end{array}$} & \multicolumn{2}{|c|}{$\begin{array}{l}\text { Inhibition of } \\
\text { Pro transport } \dagger\end{array}$} & \multicolumn{2}{|c|}{$\begin{array}{c}\text { Transport inhibited } \\
\text { by Pro } \ddagger\end{array}$} \\
\hline & C-19 & Eth $^{\mathrm{r}-2}$ & C -19 & $E^{2} h^{x}-2$ & C- 19 & $E$ th $^{r}-2$ \\
\hline \multicolumn{7}{|l|}{ Group I } \\
\hline Ala & 100 & 100 & 100 & 98 & 28 & 100 \\
\hline Cys & ND & 89 & 99 & 100 & 30 & 97 \\
\hline Gly & 100 & 100 & 100 & 100 & 52 & 99 \\
\hline Pro & 52 & 100 & 100 & 99 & 100 & 100 \\
\hline Ser & 100 & 98 & 96 & 100 & 45 & 100 \\
\hline Thr & 100 & 92 & 100 & 100 & 57 & 95 \\
\hline Val & 100 & 97 & 95 & 93 & 38 & 99 \\
\hline \multicolumn{7}{|c|}{ Group II } \\
\hline Arg & 92 & 2 & 87 & 2 & 27 & $\mathrm{NA}$ \\
\hline Asn & 100 & 3 & 60 & 0 & 57 & $\mathrm{NA}$ \\
\hline Gln & 100 & ND & 50 & ND & 64 & $\mathrm{NA}$ \\
\hline $\mathrm{His}$ & 99 & 0 & 58 & 0 & 16 & $\mathrm{NA}$ \\
\hline Ile & 100 & 2 & 81 & 0 & 38 & $\mathrm{NA}$ \\
\hline Leu & 97 & 7 & 79 & 5 & 35 & $\mathrm{NA}$ \\
\hline Lys & 94 & ND & 37 & ND & 43 & $\mathrm{NA}$ \\
\hline Met & 101 & 1 & 82 & 0 & 21 & $\mathrm{NA}$ \\
\hline Phe & 93 & 3 & 70 & 1 & 18 & $\mathrm{NA}$ \\
\hline Trp & 99 & ND & 80 & ND & 10 & $\mathrm{NA}$ \\
\hline Tyr & $\mathrm{ND}$ & ND & ND & ND & ND & $\mathrm{NA}$ \\
\hline \multicolumn{7}{|c|}{ Group III } \\
\hline Asp & 29 & 10 & 30 & 20 & 22 & 22 \\
\hline Glu & 35 & 8 & 21 & 22 & 40 & 36 \\
\hline
\end{tabular}

Since histidine preloaded in wild-type prosthecae exchanged with all unlabelled amino acids except glutamate, aspartate and proline (Fig. 5), suggesting a common transport system for amino acids of both groups I and II, we wondered if amino acids preloaded in mutant prosthecae would exchange with the full range of amino acids or only with those of group I. Prosthecae prepared from cells of the Eth ${ }^{r}-2$ mutant were preloaded with labelled glycine, and unlabelled amino acids were tested for their ability to stimulate efflux of the label. Rapid efflux was caused by all group I amino acids but no efflux was caused by those of groups II or III. Selected amino acids from the three groups were tested for stimulation of efflux of labelled glycine from preloaded wild-type prosthecae. As with the histidine exchange experiments, amino acids from both group I (glycine and proline) and II (histidine and methionine) but not from group III stimulated efflux in wild-type prosthecae. Thus, amino acids from group I (glycine) or group II (histidine), when preloaded into wild-type prosthecae, will exchange with unlabelled amino acids of both groups I and II, but a preloaded group I amino acid exchanges only with other group I amino acids in mutant prosthecae; in neither case did preloaded amino acids of groups I or II exchange with group III amino acids.

\section{Properties of amino acid transport in C-19 and Ethr-2 prosthecae}

Temperature and $\mathrm{pH}$ optima and kinetic parameters of the transport of histidine, glycine and proline in C-19 and Eth ${ }^{\mathrm{r}}-2$ prosthecae are shown in Table 6 . The results of these measurements suggest that in C-19 prosthecae histidine is transported by a single system, whereas glycine and proline are both transported by two systems. 


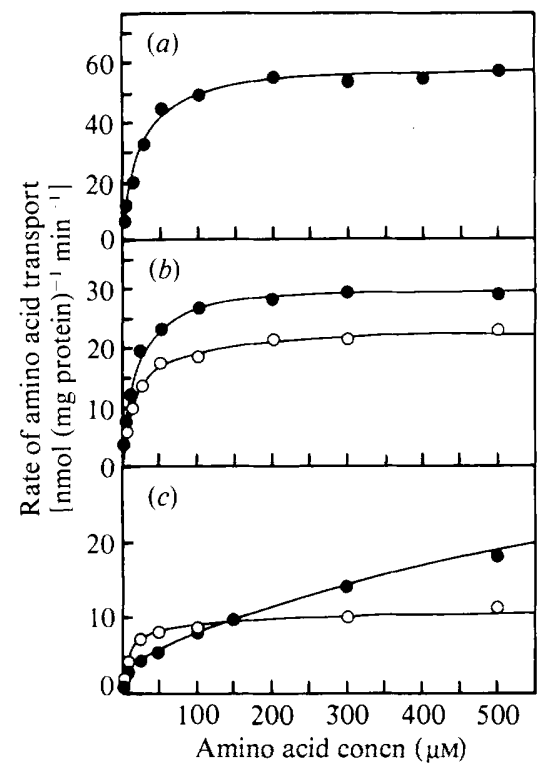

Fig. 6. Effect of ${ }^{1+C}$-labelled amino acid concentration on the initial rate of transport of amino acids by $\mathrm{C}-19(\mathrm{O})$ and $\mathrm{Eth}^{\mathrm{r}}-2(\mathrm{O})$ prosthecae. Amino acids tested were L-histidine $(a)$, glycine $(b)$ and L-proline (c). Each reaction mixture contained $50 \mathrm{~mm}-\mathrm{Tris} / \mathrm{HCl}(\mathrm{pH} 7 \cdot 4), 1 \mathrm{~mm}-\mathrm{MgCl}_{2}, 0.1 \mathrm{~mm}-\mathrm{PMS}, 20 \mathrm{~mm}-$ ascorbate and $100 \mu \mathrm{g}$ prosthecal protein. Reactions were started by the addition of ${ }^{1+} \mathrm{C}$-labelled amino acid. and samples were taken and assayed as described under 'Transport assays in Methods. The points shown represent means of triplicate samples, none of which varied by more than $10 \%$ from the mean.

Table 6. Temperature and pH optima and kinetic parameters of transport of histidine, glycine and proline in C-19 and Eth'-2 prosthecae

The basic reaction mixture contained, in a $100 \mu$ total volume: $50 \mathrm{~mm}$-buffer, $1 \mathrm{~mm}-\mathrm{CaCl}_{2}, 0 \cdot 1 \mathrm{~mm}-$ PMS, $20 \mathrm{~mm}$-ascorbate and $20 \mu \mathrm{l}$ prosthecal suspension. Buffers and $\mathrm{pH}$ ranges tested were $\mathrm{MES}$ ( $\mathrm{pH}$ $5 \cdot 0$ to $7 \cdot 0$ ) and TES (pH 6.6 to 8.6). Temperature range tested was 0 to $40^{\circ} \mathrm{C}$ in intervals of $5^{\circ} \mathrm{C}$. NA, Not applicable.

\begin{tabular}{|c|c|c|c|c|c|c|}
\hline \multirow{2}{*}{$\begin{array}{l}\text { Amino } \\
\text { acid }\end{array}$} & \multicolumn{2}{|c|}{$\mathrm{pH}$ optimum } & \multicolumn{2}{|c|}{$\begin{array}{l}\text { Temperature } \\
\text { optimum }\left({ }^{\circ} \mathrm{C}\right)\end{array}$} & \multicolumn{2}{|c|}{$K_{\mathrm{m}}\left(V_{\max }\right)^{*}$} \\
\hline & $C-19$ & Eth ${ }^{\mathrm{r}-2}$ & $C-19$ & Eth $^{\mathrm{r}-2}$ & $C-19$ & $E t^{r}-2$ \\
\hline His & $6 \cdot 6$ & $\mathrm{NA}$ & $25-35$ & NA & $15(58)$ & $\mathrm{NA}$ \\
\hline Gly & $\begin{array}{l}6 \cdot 6 \\
7 \cdot 6\end{array}$ & $6 \cdot 4$ & $25-30$ & 25 & $14(30)$ & $12(22)$ \\
\hline Pro & $\begin{array}{l}6.2 \\
7.6\end{array}$ & $6 \cdot 2$ & $25-30$ & 25 & $\begin{aligned} & 2 \cdot 5(5 \cdot 2) \\
& 134 \quad(15)\end{aligned}$ & $5(10)$ \\
\hline
\end{tabular}

* Apparent affinity constant $\left(K_{\mathrm{m}}\right)$ in $\mu \mathrm{M}$ and maximum velocity $\left(V_{\mathrm{max}}\right)$ in nmol (mg protein $)^{-1} \min ^{-1}$. Substrate concentrations used were 0.5 to $500 \mu \mathrm{M}$.

Values for the apparent $K_{\mathrm{m}}$ and $V_{\max }$ for the transport of histidine, glycine and proline (Fig. 6 , Table 6) were estimated using Lineweaver-Burk plots together with Neal's method of analysis (Neal, 1972) for diphasic double-reciprocal plots. The results for C-19 prosthecae are compatible with the presence of a single system for both histidine and glycine transport, but two systems were indicated for proline transport (one high-affinity and one low-affinity system). With Eth'-2 prosthecae, glycine was transported with an apparent $K_{\mathrm{m}}$ not significantly different from its transport in C-19 prosthecae but with a reduced $V_{\max }$, suggesting either that a single glycine transport system had been altered, or that C-19 prosthecae possess two systems that transport glycine with approximately the same $K_{\mathrm{m}}$, and that one of these systems is missing from mutant 
prosthecae. Kinetic studies revealed a single system of proline transport in Eth ${ }^{\mathrm{r}} \mathrm{2}$ prosthecae, the kinetic parameters of which were similar to, but statistically different from, the high-affinity proline transport system of C-19 prosthecae. Histidine was not transported by Eth' ${ }^{\mathrm{r}}-2$ prosthecae at any concentration tested.

\section{DISCUSSION}

Prosthecae prepared from $A$. biprosthecum possess systems for active transport of all 20 amino acids tested in this study. We propose that the patterns of inhibition in competition experiments, of exchange, and of transport in prosthecae of wild-type cells and mutants are due to the presence in prosthecae of three amino acid transport systems. A general or ' $G$ ' system transports a broad range of amino acids, possibly all amino acids tested but certainly all those in groups I and II. A second system, referred to as the high-affinity proline transport or ' $P$ ' system, transports all amino acids in group I and perhaps also glutamate and aspartate, but does not transport group II amino acids. The third system transports only aspartate and glutamate and is referred to as the acidic amino acid or ' $A$ ' transport system. Simultaneous operation of these three systems would account for all the results obtained using wild-type prosthecae; results obtained using mutant prosthecae are explained by assuming that $E t^{r}$ and $\mathrm{Can}^{\mathrm{r}}$ mutants have lesions in the $\mathrm{G}$ system and possess normal $\mathrm{P}$ and $\mathrm{A}$ systems, and that Azer mutants have lesions in both $G$ and $P$ systems and possess a normal $A$ system.

Proline differs from aspartate and glutamate, and also from all other amino acids, in only partially inhibiting the transport of all other amino acids in competition experiments, but in having its own transport inhibited by other amino acids by values ranging from 20 to $100 \%$. Results from exchange experiments on prosthecae preloaded with histidine suggest that a single general system transports all amino acids except proline, aspartate and glutamate, none of which stimulate the efflux of preloaded histidine, but this does not explain the patterns of inhibition seen with these three amino acids in competition experiments. If these amino acids are transported by the general system, why do they not stimulate exchange of histidine? If they are not, why is there competition (even partial competition) with amino acids transported by the general system?

Characteristics of certain amino acid analogue-resistant mutants suggest answers to the above questions. Mutants of the classes $\mathrm{Eth}^{\mathrm{r}}$ and $\mathrm{Can}^{r}$, selected for their resistance to methionine and arginine analogues, respectively, are all defective in amino acid transport. Characteristics of these mutants strongly suggest that they all possess the same defect: loss of transport by a general amino acid transport system. Prosthecae from these mutants all fail to transport any of the eleven amino acids in group II (Table 5); they transport aspartate and glutamate at a rate approximately $30 \%$ lower than that of wild-type prosthecae, and transport the seven amino acids of group I normally. These results taken by themselves suggest that group I amino acids are not transported by the general system that is defective in these mutants, but taken together with earlier competition experiments and with exchange experiments on mutant and wild-type prosthecae, the results suggest that amino acids in group I are transported by two systems: one that transports only amino acids of group I (P system) and another that transports amino acids of both groups I and II (G system). Arguments in favour of these interpretations are as follows. (i) Inhibition of the transport of group I amino acids by group II amino acids in wild-type prosthecae but not in $\mathrm{Eth}^{\mathrm{r}}-2$ prosthecae can only mean that a transport system shared by amino acids of both groups is present in wild-type prosthecae and missing from mutant prosthecae. (ii) The partial inhibition by proline of transport of other group I amino acids in C-19 prosthecae and their complete inhibition in Eth'-2 prosthecae would be expected if group I amino acids are transported by both systems and if proline is a poorer substrate and competitor for transport by the G system than by the P system. (iii) Glycine (group I) preloaded in Ethr-2 prosthecae exchanges with amino acids of group I but not with those of group II, but when preloaded in C19 prosthecae exchanges with amino acids of both groups. These results mean that amino acids of groups I and II share a common system in wild-type prosthecae that is not operating in mutant prosthecae. (iv) Exchange experiments with histidine preloaded in wild-type prosthecae also 
show that group I amino acids, with the possible exception of proline, share a transport system with those of group II, and the failure of proline to elicit a measurable efflux of histidine would be explained if proline is a poor substrate of the general system. (v) The observation that in competition experiments on wild-type prosthecae proline transport is completely inhibited by all group I amino acids and only partially inhibited ( 20 to $87 \%$ ) by group II amino acids, and that proline only partially inhibits the transport of any other amino acid (group I or II), again suggests that proline is transported by both systems but only weakly by the general system.

Comparison of the specific characteristics of transport of glycine, proline and histidine in C19 and $E t^{r}-2$ prosthecae further supports the above interpretations. Broad temperature optima seen for all three amino acids in C-19 prosthecae were replaced by sharp temperature optima for glycine and proline in Ethr-2 prosthecae. The two $\mathrm{pH}$ optima obtained for the transport of both glycine and proline in wild-type prosthecae, and the single optimum obtained for each of these amino acids in mutant prosthecae, further support the interpretation that glycine and proline are transported by two systems, one of which is defective in Eth ${ }^{\mathrm{r}}-2$ mutants. Comparison of the kinetic parameters for transport of glycine, proline, and histidine in wild-type and mutant prosthecae also suggests that wild-type prosthecae possess two systems that transport both proline and glycine and a single system for histidine. Comparison of apparent $K_{\mathrm{m}}$ values obtained for proline transport in Eth'-2 prosthecae with those obtained with C-19 prosthecae show that the high-affinity system $\left(K_{\mathrm{m}}=5 \mu \mathrm{M}\right)$ is retained by mutants and the low-affinity system $\left(K_{\mathrm{m}}=134 \mu \mathrm{M}\right)$ is lost. These results explain the unusual behaviour of proline in competition and exchange experiments on wild-type cells. If proline is a poor substrate for the $G$ system it should also be a poor competitor for transport with other amino acids of that system. When both $\mathrm{G}$ and $\mathrm{P}$ systems are operating (wild-type prosthecae), proline only partially inhibits the transport of any amino acid in group I or II, because complete inhibition of the transport of group II amino acids via the $P$ system still allows their transport via the $G$ system, which is only weakly inhibited by proline.

Although broad-range amino acid transport systems are common among eukaryotic cells (Benko et al., 1969; DeBusk \& DeBusk, 1980; Grensen et al., 1970; Munck, 1972), the general rule for amino acid transport in bacterial systems previously described is for each organism to have many systems, each with high affinity for substrate entry (in the range $10^{-7}$ to $10^{-8} \mathrm{M}$ ) and specific for only one to three amino acids (Anraku, 1978). A few exceptions to the rule have been described (Johnson \& Vishniac, 1970; Stark \& Yankofsky, 1981; Kelly, 1971), but even in those cases, the number of amino acids transported by a single system did not exceed seven. Inhibitory effects of amino acids on the growth of Caulobacter crescentus were reported, and mutants resistant to amino acid inhibition were found to be defective in transport of a mixture of labelled amino acids, suggesting the possibility of a broad-range amino acid transport system in that organism also (Ferber \& Ely, 1981). Similarly, growth of A. biprosthecum in a complex medium was inhibited by the addition of any of thirteen amino acids; six other amino acids stimulated growth when added to the same medium (Pate et al., 1973). It seems likely now that growth inhibition was due to interference with transport of other amino acids by the inhibiting amino acid. It is noteworthy that the stimulatory amino acids included glutamate, aspartate and proline, for which the $G$ system has slight or no affinity.

High affinity and low specificity were suggested as attributes that should be characteristic of transport systems of ideal oligotrophs (Poindexter, 1981); this was also suggested in reference to sugar transport in $A$. biprosthecum (Larson \& Pate, 1976). How can the low-affinity systems described here be reconciled with the oligotrophic nature of the organism? One possibility is that nutrient-poor environments provide strong selective pressures for broad-range transport systems, but that the limitations of such systems prevent them from ever evolving to highaffinity systems. The results of competition and exchange experiments with the transport systems described here demonstrated possible disadvantages of broad-range transport systems. If the $K_{\mathrm{m}}$ of a general transport system is close to the external concentration of amino acids normally encountered by the organism, and if one amino acid is present at a higher concentration than the others or is transported with a higher affinity than the others, it will inhibit transport of all other amino acids. Another problem that might be encountered with 
high-affinity transport systems in oligotrophic organisms, regardless of the specificity of the system, has to do with energy requirements to operate the system. High-affinity transport systems operating under conditions where the substrate concentration is very low would result in the creation of steep solute concentration gradients across the plasma membrane, which would be metabolically expensive to establish and maintain. With these considerations in mind, prosthecae appear to be extremely effective adaptations for competition in nutrient-poor environments, providing broad-range, low-affinity transport systems incorporated into a greatly enlarged surface area projecting out from the cells that produced them. Growth rates of mutants in complex and defined media demonstrated that cells with prosthecae with defective amino acid transport systems were at a disadvantage when supplied with amino acids as nutrients (complex medium) but not when utilizing glucose and ammonia (defined medium). These results support the idea that any amino acid transport systems localized in the cell proper must be the same as those of prosthecae and that no additional systems are present in the cell. The results also provide additional evidence that the mutants are defective in specific amino acid transport systems and have no other kind of metabolic defects.

This research wass supported by the College of Agricultural and Life Sciences, University of Wisconsin, Madison, Wisconsin, and by grant GMl9859 from the National Institutes of Health.

\section{REFERENCES}

ANRAKL, A. (1978). Active transport of amino acids. In Bacterial Transport. pp. 171219. Edited by B. P. Rosen. New York: Marcel Dekker.

BeNKo. P. V.. WOOD. T. C. \& SEgel, I. H. (1969). Multiplicity and regulation of amino acid transport in Penicillium chrosogenum. Archives of Biochemistry and Biophlisics 129. 498508.

BRADFORD, M. (1976). A rapid and sensitive method for the quantitation of microgram quantities of protein utilizing the principle of protein-dye binding. Analytical Biochemistry 72, 248253

DeBusk. R. M. \& DeBusk. A. G. (1980). Physiological and regulatory properties of the general amino acid transport system of Neurospora crassa. Journal of Bacteriolog! 143.188 197.

Ferber, D. M. \& Ely. B. (1981). Amino acid resistance in mutants of Caulohacter crescentus. Ahstracts of the Annual Meeting of the American Socicty for Microhiologl. p. 107.

Grensen, M., Hol, C. \& Crabeel. M. (1970). Multiplicity of the amino acid permeases in Sacthoromyces corcisice. IV. Fvidence for a general amino acid permease. Joumal of Bacteriology 103, 770777.

JOHNSON. C. L. \& VishniaC, W. (1970). Growth inhibitions of Thiohacillus neapolitumus by histidine. methionine, phenylalanine and threonine. Journal of Bateriology 104, 11451150

Jorda... T. L.. Porter, J. S. \& Pate, J. L. (1974). Isolation and characterization of prosthecate of

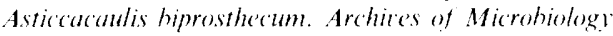
96, I 16

KelLY, D. P. (1971). Nutotrophy: concept of lithotrophic bacteria and their organic metabolism. Anmual Rerien of Microhiology 25, 177210.

I ARSON, R. J. \& PATE, J. L. (1975). Growth and morphology of Asticcacaulis hiprosthecum in defined media. Archires of Microhiologg 106, $147 \quad 157$.
Larson, R. J. \& Pate, J. L. (1976). Glucose transport in isolated prosthecae of Asticcacaulis biprosthecum. Journal of Bacteriology 126, 282-293.

Middleton, C. A. \& Pate, J. L. (1976). Isolation and partial characterization of some new bacteriophages active against Asticcacaulis strains. International Journal of Systematic Bacteriology 26, 269-277.

MU.NCK, B. G. (1972). The number and specificities of transport mediators for intestinal transport of amino acids: structural and methodological aspects. In Transport Across the Intestine, pp. 169-185. Edited by W. L. Burland \& P. D. Samuel. Edinburgh \& London: Churchill Livingstone Press.

NeAL. J. L. (1972). Analysis of Michaelis kinetics for two independent saturable membrane transport functions. Journal of Theoretical Biology 35, 113-118.

Pate. J. L., Porter, J. S. \& Jordan, T. L. (1973). Asticcacaulis biprosthecum sp. nov. Life cycle, morphology and cultural characteristics. Antonie ran Leerwenhoek 39, 569-583.

Porndexter. J. S. (1964). Biological properties and classification of the Caulohacter groups. Bacteriologi(a) Rericus 28, 231-295

Poindexter, J. S. (1981). Oligotrophy: fast and famine existence. Adrances in Microbial Ecology 5. $63-69$.

Porter, J. S. \& Pate, J. L. (1975). Prosthecae of Asticcacaulis hiprosthecum: system for the study of membrane transport. Journal of Bacteriology 122. 976-986.

ROSENBERG, T. \& WiLbraNdT, W. (1957). Uphill transport induced by counterflow. Journal of General Phisiology 41, 289-296

Stark. A. A. \& Yankofsky, S. A. (1981). Active transport of amino acids in Thiobacillus thioparas. Journal of Bacteriology 148. 956965. 